\title{
CHAPTER 4 \\ ECONOMICS OF THE FUTURE: SYNERGETICS \\ OF MODERNIZATION OF SCIENCE \\ AND THE REAL ECONOMY
}

\section{Derkach T. V.}

\author{
Science never solves a problem \\ without creating ten more. \\ George Bernard Shaw \\ The Nobel Prize Laureate in Literature
}

\section{INTRODUCTION}

In any given country, every person and society as a whole wants to live in prosperity and material independence. It is unlikely that anyone will doubt that most of the inhabitants of the planet want to have a comfortable house or apartment, to buy goods that they like, travel around the world and enjoy their impressions, receive moral and material satisfaction from living in a developed and respected country. However, there are not enough goods and services for all members of society over the limited and uneven distribution of resources. Therefore, ensuring proper welfare is not easy. Different sectors of society and professional groups have a heterogeneous level of prosperity - some people own billions of dollars, others eke out a miserable existence. These social groups often misunderstand each other, and this circumstance gives rise to economic conflicts, which sometimes turn into confrontations and even civil wars.

The economy is intended to find answers to numerous economic issues associated with the uneven distribution of incomes, living standards, inflation, and unemployment. Defining the goal of economic science, the "father of economics" A. Smith pointed out that "it proposes to enrich both the people and the sovereign"

\footnotetext{
${ }^{1}$ Смит А. Исследование о природе и причинах богатства народов. Москва : Соцэкгиз, 1962. 684 с.
} 
Economics - a science that develops and should develop gradually and continuously. At first glance, some of the best works of contemporary authors contradict the works of their predecessors. Meanwhile, when these new studies fall into place over time and their critical acuteness is removed, it turns out that in reality they do not violate the continuity of the process of development of science. New doctrines only supplement the old ones, expand, develop, sometimes correct them, often give them a different tone, emphasizing in a new way, but very rarely subvert them ${ }^{2}$.

Despite the fact that more than two and a half centuries have passed since the definition of this concept, it still remains the most concise, capacious, and correct. Add to it only small touches. Economics is a scientific discipline that studies the issues of improving the welfare of the people and the country, provided that the economic processes are balanced and social justice is respected.

It is not possible to solve this complex and multifaceted economic task without scientific analysis, research into the development trends of the economic system, and the establishment of interconnections between economic and social phenomena.

Economic science is often called the "queen of the social sciences," thereby confirming its special merits to human civilization. And although, as an independent branch of science, it exists for a relatively short time, it has earned this status. Because, just 500 years ago, the first school of economic science, namely the school of mercantilism, arose. And just then definitions of the subject-matter, methods, and tasks of economic science were formulated. One cannot but recall the words of P. Samuelson that the "birthday of political economy" is determined by mercantilist theory.

The relevance of modernization of economic science is also determined by the inconsistency of the traditional division of the economics into micro and macro due to its growing complexity and, therefore, insufficiency to understand the ongoing economic processes, including the causes of recurring and increasingly global crises. It is also the spread of the ideas of synergetics in the scientific world and the formation of the evolutionary synergetic paradigm of the analysis of socio-economic systems.

\footnotetext{
${ }^{2}$ Маршалл А. Принципы политической экономии. Пер. с англ. Москва : Прогресс, 1983, т. 1.415 с.
} 


\subsection{Evolution of economic thoughts and views}

Economy is the art of making the most of life.

George Bernard Shaw

the Nobel Prize Laureate in Literature

(Maxims for Revolutionists)

The first attempts to generalize economic practice and create a new science of the proper management of the economy were undertaken by ancient Greek thinkers and philosophers Aristotle and Xenophon.

Aristotle divided economic science into two main disciplines oikonomics (the science of rational housekeeping) and chrematistics (the science of wealth). Aristotle called oikonomics (or economics) the totality of the actions of people aimed at creating material wealth. Aristotle believed that the main goal of the economy is to provide citizens of the country with everything necessary for a comfortable life. The main tasks of the economy are ensuring public welfare and meeting the needs of people ${ }^{3}$.

Xenophon introduces for the first time such important economic categories as the use and exchange value of goods, the degree of profitability (cost effectiveness) of the production of goods, proper payment, and incentives of labour.

However, the theoretical developments put forward by ancient thinkers dealt mainly with households, the agricultural sector, handicrafts, and trade relations - all that we would now call microeconomics. The economy of the country as a whole remained outside the research ${ }^{4}$.

Winner of the Nobel Prize in Economics in 1976, Friedrich Hayek immediately revealed three differences between the economy and other sciences. "First: the very subject of this science can only be precisely determined through lengthy research. Second: in our science, it is much more difficult to distinguish a real scientist from a quack. Third: a famous international award gives the economist public influence that is not comparable to scientists in other disciplines."

Of course, the first difference can immediately cause a protest. Although the understanding of the subject-matter of economics has

\footnotetext{
Поиск науки о богатстве. 21 Biz.ru Журнал о бизнесе и благосостоянии. URL: http://21biz.ru/poisk-nauki-o-bogatstve/ (дата звернення: 11.07.2019).

Поиск науки о богатстве. 21 Biz.ru Журнал о бизнесе и благосостоянии. URL: http://21biz.ru/poisk-nauki-o-bogatstve/ (дата звернення: 11.07.2019).
} 
really changed, the definition has changed over time. Based on the classical formulation, we can say that economics has always been and is a science of the creation and distribution of wealth. Nevertheless, an understanding of how wealth is created is necessary. The basis of neoclassical economic theory and, at the same time, the answer to this question is the formula of Lionel Robbins: "a person strives for reasonable goals; time and funds at his disposal are limited; at each moment of time, they can be aimed at achieving alternative goals; at every moment in time, different goals have different importance",5. Based on this, we can say that the economy is dealing with the problem of distributing limited resources between competing goals. Therefore, we can conclude that the subject-matter of economic science - a problem of distribution.

Hayek himself gave this definition: "The fundamental goal of economic analysis is to determine how a dynamic production system uses the scattered information of time and place in a way that adjusts production plans to consumer demand" 6 . An interesting explanation of the second difference between economics and other sciences is given by Hayek himself. It is the following: in the case when economists put forward ideas that contradict the views of the layman, those immediately appear who offer him an explanation that is quite understandable, albeit erroneous. The third distinguishing feature of the economy is that all people face economic problems. And everyone wants to get recommendations on how to solve these problems. And thus, the economist who has received world recognition becomes an indisputable authority ${ }^{7}$.

The famous economist J. Schumpeter said on the changes in economic science that modern economic science has arisen based on practical and philosophical studies in various fields: from the study of the trade balance to discussions about the legality of charging interest ${ }^{8}$.

Lionel Robbins in his classic Essay on the Nature and Significance of Economic Science (chapter 3) comes close to the viewpoint of the Austrians. However, he is better known for his definition of economic theory as "a science that explores human behaviour as a connection between goals and the rare means of achieving them, which can be used in different ways."

\footnotetext{
5 Лайонел Роббинс. Предмет экономической науки. THESIS, 1993. Вып. 1. С. 10-23.

${ }^{6}$ Gary S. Becker. Economic Analysis and Human Behavior. THESIS, 1993. № 1. Pp. 24-40.

${ }^{7}$ Gary S. Becker. Economic Analysis and Human Behavior. THESIS, 1993. № 1. Pp. 24-40.

${ }^{8}$ Schumpeter J.A. Epochen der Methoden- und Dogmengeschichte.
} 
"Economic theory - a science that studies human behaviour from the viewpoint of the relationship between goals and limited means, which can have different uses"9.

According to this definition, economic science does not deal with any particular class of social phenomena (such as the production of goods, their distribution, exchange or consumption). Economic science deals with a specific aspect of human behaviour. The decision of a person to have children or violate the marriage-bed is, according to Robbins, the same part of economics as supply and demand in the tuna market. ${ }^{10}$

"Economic science investigates the normal functioning of human society; it studies the sphere of individual and social actions, which is closely connected with the creation and use of the material foundations of welfare" $"$.

According to Professor Pigou, economics examines economic welfare, which, in turn, is defined as "a welfare area where you can directly or indirectly apply the monetary scale of measurement"12.

They insisted that economics study a certain type of social behaviour, driven by the institutions of an individualistic market economy. From this point of view, any kind of behaviour that is not social in this specific sense does not belong to the subject-matter of economic science. Professor Amonn developed this concept especially vigorously ${ }^{13}$.

Of course, it should be noted that despite the wide and diverse interpretation of the definitions of economic science, the main attention is paid to the problems of a market economy.

At first glance, the differences between them are not so great. One of them relates human behaviour, driven by a comparison of goals and means, to the subject-matter of economic science, the other - the causes of material well-being. In fact, we are talking about the same thing, though $^{14}$.

Among the main definitions of economic science, there are three main but quite opposing definitions of economics. So, according to the

\footnotetext{
9 Лайонел Роббинс Предмет экономической науки. THESIS, 1993. № 1. С. 10-23.

10 Дэниел Хаусман. Философия экономики - Антология. Пер. с англ. Москва : Изд. Института Гайдара, 2012. 520 с.

${ }^{11}$ Маршалл А. Принципы политической экономии. Пер. с англ. Москва : Прогресс, 1983, т. 1.415 с.

${ }^{12}$ Пигу А.С. Экономическая теория благосостояния. Пер. с англ. Москва : Прогресс, 1985. т. 1. 512 с.

${ }^{13}$ L. Robbins. An Essay on the Nature and Significance of Economic Science. 2nd ed. London: Macmillan, 1935. Part. 1. Pp. 1-23.

${ }^{14}$ Лайонел Роббинс Предмет экономической науки. THESIS, 1993. № 1. С. 10-23.
} 
first, it studies the distribution of material goods for the satisfaction of material needs, according to the second one - market sector and, according to the third definition, it studies the distribution of limited funds to meet competing goals ${ }^{15}$.

If we analyse the first definition of economic science from the point of view of material goods, then it is without a doubt limited and does not provide a true understanding of a market economy. For example, in the United States, less than half of all those working in the market are now engaged in the production of tangible goods, and the intangible output of the service sector exceeds the value of the commodity output. Moreover, it is precisely the definitions of economic science by professors E. Cannan ${ }^{16}$, A. Marshall ${ }^{17}$, and V. Pareto ${ }^{18}$ are associated with the study of the causes of material well-being.

Moreover, in our opinion, the meaning of the definition lies, first of all, in its use.

According to Lionel Robbins ${ }^{19}$, an understanding of economics through the definition of "rarity" is interesting. So, Lionel Robbins claims that "from the point of view of an economist, the conditions of human existence are characterized by the following four fundamental provisions: a person strives for different goals; time and means at his disposal are limited; they can be aimed at achieving alternative goals; at each point in time, different goals are of different importance. It is the rarity of the means intended to meet the goals of different importance this is an almost universal property of the environment in which human activity takes place" 20 .

The most general and broad is the definition of economic science in terms of limited resources and competing goals. It proceeds from the specific nature of the problems to be solved, and covers a much wider area than the market sector or "what economists do." Rarity and choice characterize any resources, in whatever form their distribution takes place - within the framework of the political process (including decisions about which industries to tax, how to quickly expand the money supply, and whether to enter the war), through the family (including the choice of spouse and planning family sizes, determining

\footnotetext{
${ }^{15}$ Gary S. Becker. Economic Analysis and Human Behavior. THESIS, 1993. № 1. C. 24-40.

16 Лайонел Роббинс Предмет экономической науки. THESIS, 1993. № 1. С. 10-23.

${ }^{17}$ Маршалл А. Принципы политической экономии. Пер. с англ. Москва : Прогресс, 1983, т. 1. 415 с.

${ }^{18}$ Pareto V. Cours d'économie politique professé à l'université de Lausanne. Lausanne: Rouge. 1897. 426 p.

19 Лайонел Роббинс Предмет экономической науки. THESIS, 1993. № 1. C. 10-23.

${ }^{20}$ Лайонел Роббинс Предмет экономической науки. THESIS, 1993. № 1. С. 10-23.
} 
the frequency of church attendance, and the distribution of time between sleep and wakefulness), or when organizing scientific research (including the allocation by scientists of their time and mental efforts for various scientific problems) and so on ad infinitum ${ }^{21}$.

Based on the foregoing, we can note that economic science itself and the needs for it evolve according to their own laws and, at the same time, independently of each other. The needs of people stimulate the development of science, and the development of science leads to the growth and qualitative transformation of human needs. The needs for science and the possibilities of science push each other and move humanity upward in the direction of social development to new frontiers of scientific achievements and living standards. ${ }^{22}$

Thus, the specifics of the current stage of development is not so much in new scientific research but primarily in the effective application and implementation of existing knowledge, we need not discoveries independently but innovations on how to apply existing discoveries. And then it is possible to reduce the imbalance between needs and opportunities.

\subsection{Synergetics of modernization of theory and practice}

Science is but an image of the truth.

Francis Bacon

English philosopher

At present, the potentialities of science are quite significant, however, applied research, unfortunately, lags behind over its inapplicability.

Based on the analysis of the development of economics and the approaches on which its development is drawn upon, today there is a clear understanding of the laws and mechanisms of the functioning of the economic system. Herewith, countries of the world, regardless of their level of development, are constantly confronted and forced to solve serious economic challenges and problems that, it would seem, should no longer arise. And this is associated not with the problems of the

\footnotetext{
${ }^{21}$ Gary S. Becker. Economic Analysis and Human Behavior. THESIS, 1993. № 1. C. 24-40.

22 Евгений Балацкий Экономическая наука на современном этапе: кризис или прорыв? Капитал страны. Интернет-издание: веб-сайт. URL: http://kapital-rus.ru/articles/article/ekonomicheskaya_nauka_ na_sovremennom_etape_krizis_ili_proryv/(дата звернення: 10.07.2019).
} 
development of economics but with the weakness in using its capabilities.

It can even be argued that the economic success of a particular country is not directly related to the potential of economics that it possesses. The most illustrative example is Germany, which does not have a strong economic school but has a strong economy. Japan, which is associated worldwide as an "economic miracle", also cannot boast of the outstanding development of economic science. The paradox lies in the ability to apply economic knowledge while not going into subtleties of economic theory. If we analyse the economic success of China, we can notice the same trend. For example, in relation to the US Federal Reserve System (FRS), G. Soros wrote that the key to its effective work lies in the skilful combination of science and pragmatism. If the US FRS tried to implement all modern economic science in its practice, then most likely it would come to terrifying results ${ }^{23}$.

Currently, not so much in-depth studies of the economy are required, but first of all, specialists who would be able not only to use the "wealth" of economics existing today and also economists who would be able to modernize economics in view of the practical needs and emerging diversity of international economic relations.

Unfortunately, the enthusiasm of theoretical economists for endless theoretical computations, often without practical results, does not allow the further development of economic science in relation to new conditions.

According to researchers, one can state the existence of crisis trends in economics ${ }^{24}$. Thus, economics has in its arsenal two fundamental laws formulated in the work of Hermann Heinrich Gossen, "The Laws of Human Relations and the Rules of Human Action Derived Therefrom" $"$. According to the first law of $\mathrm{H}$. Gossen, namely, the law of diminishing marginal utility, with increasing consumption of one product (at a constant consumption of all the others), marginal utilities are diminishing, i.e. the overall utility is increasing at a slower rate, and decreasing - at a higher rate.

\footnotetext{
${ }^{23}$ Балацкий Е. Экономическая наука на современном этапе: кризис или прорыв? Капитал страны. Интернет-издание: веб-сайт. URL: http://kapital-rus.ru/articles/article/ekonomicheskaya_nauka_na_ sovremennom_etape_krizis_ili_proryv/ (дата звернення: 10.07.2019).

${ }^{24}$ Балацкий Е. Экономическая наука на современном этапе: кризис или прорыв? Капитал страны. Интернет-издание: веб-сайт. URL: http://kapital-rus.ru/articles/article/ekonomicheskaya_nauka_na_ sovremennom_etape_krizis_ili_proryv/ (дата звернення: 10.07.2019).

${ }^{25}$ Hermann Heinrich Gossen. The Laws of Human Relations and the Rules of Human Action Derived Therefrom. Nicholas Georgescu-Roegen MIT Press, 1983. 465 p.
} 
The second law of diminishing marginal efficiency states that, as a certain production resource grows, the marginal return (productivity) from it decreases. Despite the fact that the law of $\mathrm{H}$. Gossen is manifested in the sphere of consumption, and that the law of decreasing marginal efficiency - in the production sphere, both of these laws are a consequence of the same economic principle. The listed laws are not absolute and in some cases can still be violated. However, if they are carried out and, at the same time, manifested in a rather strong form, this indicates a certain crisis in the studied area ${ }^{26}$.

If to apply the law of $\mathrm{H}$. Gossen to economics, we come to the conclusion that the accumulation of new scientific knowledge brings less and less benefit to mankind. The law of diminishing marginal utility - the growing financial, material, and labour costs of science give less and less scientific results. "Even the most superficial look at modern economic science allows concluding that both laws are fully applicable to it" ${ }^{\text {27 }}$.

The modernization of economic science is determined by the fact that, unlike many exact sciences, it does not give unambiguous assessments and forecasts of processes and phenomena. For example, this concerns the forecast of world financial and economic crises that usually "unexpectedly" arise, trends in the development of the world economy, states, and individual industries.

Moreover, economists are constantly arguing about the causes of economic phenomena, about ways to improve the quality of life of the population, about methods of intensifying economic growth, about the amount of taxes and directions of business development. So, R. Feynman said that "...the economy is dealing with constantly changing, very subtle properties of human nature" 28 .

Based on the position of A. Poincare that any science is a system of relations ${ }^{29}$, the task of economic science according to A. Marshall is "to collect facts, systematize, interpret them and derive appropriate conclusions from them" ${ }^{30}$. And in order to understand the essence of the

\footnotetext{
${ }^{26}$ Hermann Heinrich Gossen. The Laws of Human Relations and the Rules of Human Action Derived Therefrom. Nicholas Georgescu-Roegen MIT Press, 1983. 465 p.

27 Балацкий Е. Экономическая наука на современном этапе: кризис или прорыв? Капитал страны. Интернет-издание: веб-сайт. URL: http://kapital-rus.ru/articles/article/ekonomicheskaya_nauka_na_ sovremennom_etape_krizis_ili_proryv/(дата звернення: 10.07.2019).

${ }_{28}$ Фейнман Р. Характер физических законов. Москва : Наука, 1987. 160 с.

29 Пуанкаре А. О науке. Пер. с фр. / Под ред. Л. С. Понтрягина. 2-е изд., стер. Москва : Наука, $1990.736 \mathrm{c}$.

${ }^{30}$ Маршалл А. Принципы экономической науки. В 3-х т. Москва : Прогресс, 1993. 594 с.
} 
economy, let us turn to the statement of J. Schumpeter that the roots of the economy lie, on the one hand, in philosophy, and on the other, in disputes about pressing problems and difficulties ${ }^{31}$.

In the continuation of the study of economic science, the work of the French professor T. Piketty "Capital in the Twenty-First Century",32 (2015), which in general stands apart, is of undoubted interest. The author focuses on the problem of inequality. This is just one of the key problems that need to be addressed. And the modernization of economic science is called upon to try to find an answer in the modern conditions of globalization and growth, both of regional and mega-regional integration groups.

T. Piketty's work is devoted to the topic of capital, one of the central topics in economics. This is a kind of modern continuation of the study of the topic of capital, first raised by K. Marx in the work "Capital. A Critique of Political Economy"33, and further continued by John Hicks in the book "Value and Capital" 34 , then Giovanni Arrighi in the work "The Long Twentieth Century",35, and then in our time by T. Piketty. In his research, he argues that inequality is the main problem and challenge of modern society "the distribution of wealth - one of the most pressing and discussed issues..." .

Of course, the complexity of economics, its close relationship with most other sciences (natural, humanities, mathematics), its relationship with complex multidimensional systems, which themselves have a high degree of uncertainty, do not allow to get rid of the unpredictability of economic phenomena and processes.

However, all the above difficulties and errors in forecasts do not undermine the authority of economic science in the eyes of the world community. Recall that out of all humanities, the annual Nobel Prize winners are determined only for economics. This emphasizes the special importance of economics for improving people's lives.

\footnotetext{
${ }^{31}$ Барр Р. Политическая экономия. В 2-х т. Пер. с фр. Т. 1. Москва : Международные отношения, 1995. $608 \mathrm{c}$.

${ }^{32}$ Piketty, T. Capital in the twenty-first century, translated by Arthur Goldhammer. The Belknap Press of Harvard University Press, Cambridge, Massachusetts, London, 2014. 452 p.

${ }^{33}$ Marx, K. Capital. Criticism of political economy / In: Marx K., Engels F. Coll. papers, vol. 23. Moscow: State Publishing House of Political Literature, 1960. (in Russian)

${ }^{34}$ Evgeny V. Balatsky. The effect of Piketty: a comment to new concept // Terra Economicus. 2017. T. 15. № 2. Pp. 40-56.

${ }_{35}$ Arrighi, G. The Long Twentieth Century: Money, Power, and the Origins of Our Times. London: Verso, 1994.

${ }^{36}$ Piketty, T. Capital in the twenty-first century, translated by Arthur Goldhammer. The Belknap Press of Harvard University Press, Cambridge, Massachusetts, London, 2014. 452 p.
} 
The modernization of science is a push in the development of an innovative economy and the creation of modern high-tech industry. Countries that did not have strong science, as the industry developed, were faced with the need to develop science, as was the case in Japan, Finland, and South Korea.

Science is developing in highly developed countries: they need it to accelerate the development of modern technologies and provide training for qualified specialists who could influence national and global processes.

The word "modernization" means improving, perfecting something, and not for the sake of modernization itself but for the sake of the subsequent successful solution of pre-set tasks.

By modernization, Chinese scientists understand both the development process with the introduction of "modern features" and the state that is the end result of this process.

The adjective "modernized is a characteristic of an object that is at a high level of world development or satisfies the requirements of the present" ${ }^{37}$. Professor He Chuanqi from China distinguishes between primary and secondary modernization. "If the first (primary stage) - a classic modernization, which includes industrialization, urbanization, democratization, and a rational approach, then the second (secondary) is already 'neo-modernization', for which the concepts of scientific knowledge, information, globalization, and environmental protection take on meaning",38.

By modernization, we mean the possibility of ensuring stable economic growth, a qualitative renewal of the economy, and increasing its efficiency based on the development of scientific and technological potential. Given that science is the "main productive force", it is its development that is the most important condition for ensuring economic growth $^{39}$.

In our opinion, the modernization of science is necessary and should be carried out, first of all, with a clear understanding and formulation of interests. Modernization should be adequate to the level and complexity of the national economic problems facing society and

\footnotetext{
${ }^{37}$ Обзорный доклад о модернизации в мире и Китае (2001-2010) / под ред. Хэ Ч. и Лапина Н. И. Москва : «Весь мир», 2011. 256 с.

38 Обзорный доклад о модернизации в мире и Китае (2001-2010) / под ред. Хэ Ч. и Лапина Н. И. Москва : «Весь мир», 2011. 256 с.

${ }^{39}$ Реформы Дэн Сяопина: анализ опыта Китая. 21 Biz.ru Журнал о бизнесе и благосостоянии вебсайт. URL: http://21 biz.ru/reformy-den-syaopina-analiz-opyta-kitaya/ (дата звернення: 11.07.2019).
} 
the world economic system. To achieve this goal, the mobilization of intellectual and human resources is required. Naturally, funding and support, both from the state and from corporations, will be directed only to those studies that can provide innovative, practical results. Modernization of any science, including economics, is possible only if the state of the environment, which includes the modernized system, is taken into account. The world is rigidly bound by causal relations. Otherwise, the system destabilization and, as a result, its possible degradation can be observed. Further, necessary in the process of modernization of science is the inevitable change in the framework of rationality towards expanding the applied forms of thinking and recognizing the legitimacy of this expansion depending on the tasks being solved. The use of all criteria of truthfulness, depending on research subjects, should be recognized ${ }^{40}$.

It seems that it would be right to make corrections and create new organizational forms of research, namely, the creation of structures that would be organized for specific tasks, in the solution of which there are interested customers.

The modernization of science cannot be achieved without the development of the applied level of the humanities. Along with the transition to the post-industrial stage of development, mankind is moving to new technologies for the development and management of needs. This transition is a qualitative restructuring, or bifurcation point, opening a new window of opportunity. The economic system has such states when it becomes different, but the economic fundamental theory is not able to catch these transitions, even at the most general level.

Among the priority areas of modernization of economic science, a special place belongs to the need to move to the implementation of the requirement to give economic science the form of verified theories.

No less important in the implementation of the modernization of economic science is the need to return to the conviction that political economy should regain the status of a single science, under the dome of which various directions of scientific research of problems of global governance and interstate regulation of economic relations in a changing political, socio-cultural environment are developing. Indeed, emerged in the 1970s as an interdisciplinary industry at the intersection of economics

\footnotetext{
${ }^{40}$ Реформы Дэн Сяопина: анализ опыта Китая. 21 Biz.ru Журнал о бизнесе и благосостоянии. URL: http://21biz.ru/reformy-den-syaopina-analiz-opyta-kitaya/ (дата звернення: 11.07.2019).
} 
and political science, the school of world political economy has all the properties to study cross-country integration, especially at the stage of formation of supranational governance structures. After all, it is a global political economy that studies and substantiates measures for their implementation by the power structures of individual states and international integration associations in a dynamic external environment, where new challenges to international economic stability regularly appear.

It is also worth noting the absolutisation of the role of mathematics in research, which sometimes occurs to the detriment of the study of pressing issues of socio-economic development. This is confirmed by the words of one of the founders of economic theory, R. Coase, "Existing economics is ... a mathematical system which floats in the air and which bears little relation to what happens in the real world" 41 . A. Marshall saw in mathematics an important, but only an auxiliary tool of economic analysis, not a substitute for a deep study of economic realities and historical precedents ${ }^{42}$.

Therefore, modern economic thinking is forced to adapt to the diversity and inconsistency of the reality of a diverse, dynamic, and very complex economic system ${ }^{43}$.

The modernization of economics also, in our opinion, without the modern "complexity economics" 44 suggests that, although selforganization mechanisms can shift complex adaptive systems to some stationary state (to the so-called attractor), they usually generate multiple equilibria, often unstable and transient. For example, in countries with market economies, the required self-organization, which could help to solve problems on the way to a certain stable attractor, namely the appearance of the necessary instrumental education in a complex environment, can be: 1) very time-consuming to have the desired effect; 2) fragile, i.e. unstable; or even 3) completely blocked. Thus, a systematic policy is needed to further contribute to the sustainable development of complex adaptive economic systems ${ }^{45}$.

\footnotetext{
${ }^{41}$ Gary S. Becker. Economic Analysis and Human Behavior. THESIS, 1993. № 1. C. 24-40.

42 Маршалл А. Принципы политической экономии. Пер. с англ. Москва : Прогресс, 1983, т. 1. $415 \mathrm{c}$.

${ }^{43}$ Khaykin M. M. Evolution of economic theory as science: the challenge of time. Научно-технические ведомости СПбГПУ. Экономические науки. 2013. №6-1(185). С. 48-53.

44 Arthur B. Complexity economics: A different framework for economic thought. SFI Working Paper: веб-сайт. URL: http://tuvalu.santafe.edu/ wbarthur/Papers/Comp.Econ.SFI.pdf (дата звернення: 05.07.2019).

${ }^{45}$ Kirman A. Complex economics: Individual and collective rationality. London, New York: Routledge, 2011.
} 
Confirmation that economic science is in a state of crisis and needs modernization is the impossibility, with all the variety of areas in economic theory and mathematical models, to describe, explain, and predict the occurrence of critical economic phenomena and processes. And most importantly, this is the lack of proposals for overcoming the crisis and the possibility of preventing destabilizing situations in both the national and global economies.

The presence of major changes in the global economy confirms the need to modernize economic science. As a result of globalization, the world has become more homogeneous and interconnected. It is dominated by one global state and its allies by civilizational criteria. There is a constant redistribution of forces in the global economic space, and new poles of economic growth are being formed. Irreversible changes have occurred in the economic structure: despite all the innovative advantages, the model of the financial economy is gradually beginning to displace the innovative economy. Financial markets have proven to be a major factor in increasing competitiveness. And against this background, reindustrialization is taking place and that is notable and justified, first of all, in highly developed countries. Thus, the postindustrial economy can be discussed mainly in the countries of postsocialist development. Theoretical postulates about the existence of a post-industrial economy as a criterion for a highly developed economy have sunk. The real industrial economy is returning, and, first of all, in the leading countries. The countries that for any reason are not capable of developing industry are beginning to fall into the category of countries with post-industrial economies ${ }^{46}$.

The return of the cyclical nature of economic development should be noted. Until 2009, in the last 15 years, there were no crises in the economies of world leaders. Leading theorists of economic science put forward assumptions about overcoming cyclicity, primarily relying on the ability of the market to self-regulate development dynamics, along with financial innovations that strengthen stability and security in the economy, through diversification and redistribution of risks across the financial system. The return of cycles indicates the need to update the

\footnotetext{
${ }^{46}$ Гринберг Р. С. Поиски новых экономических моделей как ответ на вызовы XXI века. География мирового развития. Выпуск 3: Сборник научных трудов / под ред. Л. М. Синцерова. Москва : Товарищество научных изданий КМК, 2016. С. 8-16.
} 
development of new mechanisms of countercyclical regulation based on the modernization of economic science ${ }^{47}$.

Another reason for the need to develop economic science is the return of the role of the state. More recently, the theory of "competitive liberalization" was classified as the most progressive ${ }^{48,49}$.

At the present moment, the constructive role of the state is resuming in the regulation of the economy and the emergence of its new functions. Examples include the United States, China, Germany, and other leading countries. The new functions include the protection of national economic interests, priority support for an innovative economy, and a steady trend in the development of social infrastructure of society ${ }^{50}$.

Existing economic theories are constantly being updated; modern versions are appearing. The theory of the full value of natural substance illustrates the fact that the tradition of economic analysis of the period from the end of the XIX to the first third of the XX century is built into the main tradition of the Quesnay-Ricardo-MarX-Sraffa circuit. There are three aspects to this issue: 1) a representation of the tradition of the circuit as a theoretical "background" of research by economists; 2) a description of the actual Ukrainian tradition of economic analysis of the circuit and the principle of such a description; 3) a way of connecting these two traditions in the history of economic thought ${ }^{51}$. Based on the ideas of the physiocrats, the theory of full value provides clues for an objective energy assessment of reserves and bottlenecks of social development: reserves of full value and rent in the world economic system and what prevents their appropriate use for the common good ${ }^{52}$.

All changes in socio-economic development are taking place against the backdrop of new challenges, such as an increase in anthropogenic and technogenic pressure on the ecological system,

\footnotetext{
${ }^{47}$ Гринберг Р. С. Поиски новых экономических моделей как ответ на вызовы ХХІ века. География мирового развития. Выпуск 3: Сборник научных трудов / под ред. Л. М. Синцерова. Москва : Товарищество научных изданий КМК, 2016. С. 8-16.

48 Деркач Т. В. Либерализация ВЭД в контексте ревитализации экономик интегрирующихся стран. Science and Education Studies, Volume III. "Stanford University Press”, 2015. № 2. (16). P. 166-173.

49 Деркач Т. В. Стратегия конкурентной либерализации в торговле как составляющая развития национальной экономики. Вісник Херсонського державного університету, Серія: Економічні науки. 2014. Вип. 8. Частина 5. С. 34-38.

${ }^{50}$ Гринберг Р. С. Поиски новых экономических моделей как ответ на вызовы ХХІ века. География мирового развития. Выпуск 3: Сборник научных трудов / под ред. Л. М. Синцерова. Москва : Товарищество научных изданий КМК, 2016. С. 8-16.

${ }^{51}$ Кенэ Ф. Избранные экономические произведения. Москва : Соцэкгиз, 1960.

52 Никольский А. Ф. Резервы и узкие места устойчивого развития в мировой экономической системе. География мирового развития. Выпуск 2: Сборник научных трудов / под ред. Л. М. Синцерова. Москва : Товарищество научных изданий КМК, 2010. С. 107-125.
} 
competitive relations are determined by geopolitical and economic interests, the load on natural resources is sharply increasing in the economy, and therefore, the problem of their exhaustion and, at the same time, need to increase the efficiency of raw materials' extraction. Also, inequality between countries is growing, and therefore, social contrasts are becoming sharper. Solving this issue requires the creation of new models of the social state. Science is designed to show how to solve the problems. But the very state must initiate the modernization of science. Because any modernization carries risks and losses, in turn, the state takes responsibility, encouraging a knowledge-based economy, innovative development, thereby adjusting the course of development of economic science and creating new economic models based on theoretical "mainstream", thus minimizing future losses.

\section{CONCLUSIONS}

The development of the global economy was based on increased investment in research and development, the formation of global telecommunication networks, the development of information technology, the expanded use of Internet technologies, the use of advanced technical standards and methods of corporate and state economic management.

The approach to economics as a scientific discipline and, at the same time, as a sphere of human activity, is possible only if a systematic knowledge is ensured, i.e. it is necessary to take into account the achievements of other scientific disciplines that allow the economy to harmoniously integrate into the general structure of modern scientific research. It is very difficult to change economic reality - whether it is low wages in poor countries, tax shelters serving super-rich people, excessive corporate power, or an overly complex financial system. Sometimes difficulties are caused by the active efforts of those who benefit from existing mechanisms.

The hope that economics can help to cope with poverty and support the conditions in which free people can prosper is its most inspiring mission and greatest achievement. It is economics that is always aimed at changing the structure of the world. The very first economists were advisers to the absolute monarchs in the early period of modern Europe. And today, economists continue the tradition of changing the structure of the world. 
The process of modernization of economic science, in our opinion, should be carried out based on changes in economic life. One of the most important factors that ensured the success of the Chinese reforms was the gradual, evolutionary nature of the reform process and, at the same time, the "new" modernized economic theory of the XXI century about how science should find answers to modern challenges of the time- questions that arise in the global and national economies, functioning at a qualitatively new level of development.

It is also necessary to take into account the concept of interdisciplinarity, which is especially important for economists. It is the dialogue between representatives of both various social sciences and various scientific fields that will contribute to the socio-economic development of the world system.

Since the last financial crisis for an increasing number of economists (and practitioners) it has become obvious that we need other theories and models, and not those that are associated with perfect agents and mechanisms aimed at smoothing economic processes to ensure equilibrium. The developing complexity economics is incompatible with the historical message of the mainstream that the market economy seeks a general and relatively optimal equilibrium, which is the only way, vanishing point, and end of human history.

A feature of economic science is its direct relationship mainly with human beings, who are forced to move along the path of progress and implement changes, whatever they bear.

The modernization of economic science should be aimed at a pragmatic solution to modern problems, taking into account the simultaneously occurring processes of regionalization, globalization, and glocalization.

\section{SUMMARY}

The article attempts to systematize economic ideas because economic science arose based on practical and philosophical studies in various fields of different time periods. Indeed, the understanding of the subject-matter of economics has changed, and the definition has changed over time. First of all, economics is seen as the science of the creation and distribution of wealth. The paper analyses the need for modernization of economics since there is a discrepancy between theoretical developments and the real economy. Despite the wide and varied interpretation of the definitions of economic science, the main 
attention is paid there to the problems of a market economy. The paper defines the specifics of the modern stage of development, which consists of the effective implementation of already existing theories; we need not discoveries independently but innovations on how to apply existing discoveries. The main directions of modernization of science are proposed while it should be implemented, first of all, with a clear understanding and formulation of interests. The paper concludes on the modernization of economic science of the XXI century to find answers to the challenges of the time, functioning at a qualitatively new level of development.

\section{REFERENCES}

1. Smit, A. (1962). Issledovanie o prirode i prichinah bogatstva narodov [Research on the nature and causes of the wealth of peoples]. Moskva: Sotsekgiz. (in Russian)

2. Marshall, A. (1983). Printsipyi politicheskoy ekonomii [Principles of Political Economy]. Moskva: Progress. (in Russian)

3. Poisk nauki o bogatstve [Wealth Science Search]. 21 Biz.ru Zhurnal o biznese i blagosostoyanii. URL: http://21biz.ru/poisk-nauki-obogatstve/ (accessed 11 July 2019) (in Russian)

4. Gary S. Becker. (1993). Economic Analysis and Human Behavior. THESIS, 1, 24-40.

5. Schumpeter J.A. Epochen der Methoden- und Dogmengeschichte.

6. Layonel Robbins (1993). Predmet ekonomicheskoy nauki [Subject of economics]. THESIS, 1. 10-23. (in Russian)

7. Deniel Hausman (2012). Filosofiya ekonomiki - Antologiya [Philosophy of Economics - Anthology]. Moskva: Izd. Instituta Gaydara. (in Russian)

8. Pigu, A. S. (1985). Ekonomicheskaya teoriya blagosostoyaniya [Economic Theory of Welfare]. Moskva: Progress. (in Russian)

9. L. Robbins (1935). An Essay on the Nature and Significance of Economic Science. 2nd ed. London: Macmillan, 1, 1-23.

10. Pareto, V. (1897). Cours d'économie politique professé à l'universịté de Lausanne. Lausanne: Rouge.

11. Evgeniy Balatskiy. Ekonomicheskaya nauka na sovremennom etape: krizis ili proryiv? Kapital stranyi [Economic science at the present stage: crisis or breakthrough? Country Capital]. URL: http://kapital-rus.ru/ articles/article/ekonomicheskaya_nauka_na_sovremennom_etape_krizis_il i_proryv/(accessed 10 July 2019) (in Russian) 
12. Hermann Heinrich Gossen (1983). The Laws of Human Relations and the Rules of Human Action Derived Therefrom. Nicholas Georgescu-Roegen MIT Press.

13. Feynman, R. (1987). Harakter fizicheskih zakonov [Характер физических законов]. Moskva: Nauka. (in Russian)

14. Puankare, A. (1990). O nauke [About Science]. Pod red. L. S. Pontryagina. Moskva: Nauka. (in Russian)

15. Marshall, A. (1993). Printsipyi ekonomicheskoy nauki [Principles of Economic Science]. Moskva: Progress. (in Russian)

16. Barr, R. (1995). Politicheskaya ekonomiya [Political Economy]. Moskva: Mezhdunarodnyie otnosheniya. (in Russian)

17. Piketty, T. (2014). Capital in the twenty-first century, translated by Arthur Goldhammer. The Belknap Press of Harvard University Press, Cambridge, Massachusetts, London, England.

18. Marx, K. (1960). Capital. Criticism of political economy / In: Marx K., Engels F. Coll. papers, vol. 23. Moscow: State Publishing House of Political Literature. (in Russian)

19. Evgeny V. Balatsky (2017). The effect of Piketty: a comment to new concept. Terra Economicus, 15(2), 40-56.

20. Arrighi, G. (1994).The Long Twentieth Century: Money, Power, and the Origins of Our Times. London: Verso.

21. Obzornyiy doklad o modernizatsii v mire i Kitae (2001-2010) [Overview report on modernization in the world and China (2001-2010)] / pod red. He Ch. i Lapina N. I. Moskva: «Ves mir», 2011. (in Russian)

22. Reformyi Den Syaopina: analiz opyita Kitaya [Deng Xiaoping Reforms: An Analysis of China's Experience]. 21 Biz.ru Zhurnal o biznese $i$ blagosostoyanii. URL: http://21biz.ru/reformy-den-syaopinaanaliz-opyta-kitaya/ (accessed 11 July 2019) (in Russian)

23. Khaykin, M. M. (2013). Evolution of economic theory as science: the challenge of time. Nauchno-tehnicheskie vedomosti SPbGPU. Ekonomicheskie nauki, 6-1(185), 48-53.

24. Arthur B. Complexity economics: A different framework for economic thought. SFI Working Paper. URL: http://tuvalu.santafe.edu/ $\sim$ wbarthur/Papers/Comp.Econ.SFI.pdf (accessed 05 July 2019)

25. Kirman A. (2011). Complex economics: Individual and collective rationality. London, New York: Routledge.

26. Grinberg, R. S. (2016). Poiski novyih ekonomicheskih modeley kak otvet na vyizovyi XXI veka. Geografiya mirovogo razvitiya [The search for new economic models as an answer to the challenges of the 
XXI century. Geography of world development]. Vyipusk 3: Sbornik nauchnyih trudov / pod red. L.M. Sintserova. Moskva: Tovarischestvo nauchnyih izdaniy KMK. (in Russian)

27. Derkach, T. V. (2015). Liberalizatsiya VED v kontekste revitalizatsii ekonomik integriruyuschihsya stran [Liberalization of foreign economic activity in the context of the revitalization of the economies of integrating countries]. Science and Education Studies, Volume III. "Stanford University Press", 2(16), 166-173.

28. Derkach, T. V. (2014). Strategiya konkurentnoy liberalizatsii v torgovle kak sostavlyayuschaya razvitiya natsionalnoy ekonomiki [The strategy of competitive liberalization in trade as a component of the development of the national economy]. Visnyk Khersonskoho derzhavnoho universytetu, Seriia: Ekonomichni nauky, 8(5), 34-38. (in Russian)

29. Kene, F. (1960). Izbrannyie ekonomicheskie proizvedeniya [Selected Economic Works]. Moskva: Sotsekgiz. (in Russian)

30. Nikolskiy, A. F. (2010). Rezervyi i uzkie mesta ustoychivogo razvitiya $\mathrm{v}$ mirovoy ekonomicheskoy sisteme. Geografiya mirovogo razvitiya [Reserves and bottlenecks of sustainable development in the global economic system. Geography of world development]. Vyipusk 2: Sbornik nauchnyih trudov / pod red. L. M. Sintserova. Moskva: Tovarischestvo nauchnyih izdaniy KMK. (in Russian)

\section{Information about the author: Derkach T. V.} Doctor of Economic Sciences, Head of the Department of Management, International Humanitarian University, Ukraine 